presence of the laboratory and its team of scientists of international reputation whose work is so ably summarised in this book.

JOHN CLEGG

\title{
A Field Guide to the Butterflies of Britain and Europe, by Lionel \\ C. Higgins and Norman D. Riley. Collins, 42 s.
}

Those who are interested in butterflies, as distinct from moths, have long felt the need of a book of this kind. The resident British species, 59 in all, do not provide sufficient scope, and those who study and collect butterflies usually cover the whole of Europe. The scope of this book is wide enough to meet this need, for it includes Europe west of the Iron Curtain, northwest Africa, Madeira, the Canaries and the Azores. Every species, a total of $38 \mathrm{r}$, is figured, showing both upper and under sides, and the figures are extremely good. They are life-sized, which is a most important aid to identification, especially for beginners. In addition, flight-times, habitats, range, food-plants, points for identification and local forms are dealt with. With its aid, the butterfly enthusiast should be able to identify any species that he may encounter in the wide area covered by the book. An excellent feature is the distribution maps given for each species. There is a good index, and the book is very well printed and produced. At 42s. it is remarkably good value.

R. SAUNDBY

\section{Brief Reviews}

The Mammals of Fasper Park, Alberta, by J. Dewey Soper, Canadian Wildlife Service Report Series No 10, $\$ 2.50$, gives a systematic account of the 52 native mammals in this national park, established in 1907; they include black bear (only 'a few pairs' survive the 'ruthless extermination for its fur' before the park was created), marten ('well represented'), fisher, mountain lion (seldom seen), wood caribou, and bighorn sheep. Chapters include history, natural history, naturalists, and there is a selected bibliography and map.

Birds of Isla Grande (Tierra del Fuego), by P. S. Humphrey, D. Bridge, P. W. Reynolds and R. T. Peterson, gives a species by species account of an avifauna about which information 'is scant at best' together with good detailed maps and 2I plates of black and white paintings by J. R. Schroeder designed (and good) for identification, although this is no pocket guide with 400 pages, II in $\times 8 \frac{1}{2}$ in. (A pity these could not have been issued loose.) Obtainable from University of Kansas Museum of Natural History, Lawrence, Kansas 66044, \$7.00.

The Avifauna of Northern Latin America, edited by Helmut K. and Jimmie H. Buechner, Smithsonian Institution Press, US \$3.25, is the recently published proceedings of a symposium held in April 1966 with a synthesis of the suggestions made during the discussion. Papers were read on the avifauna of 8 countries: Guatemala, Honduras, British Honduras, Panama, Nicaragua, Mexico, Venezuela and Colombia.

Collins Guide to Tree Planting and Cultivation, by H. L. Edlin (42s) is for the landscape planner and the forester. Part $\mathbf{I}$ (Tending Trees) goes into every detail of cultivation; Part 2 (Choosing Trees) describes all the likely species, with notes on special growth forms, colour variations, hedge bushes, shelterbelts, dwarfs, trees for special soils and situations, with useful lists of arboreta open to the public and of journals, libraries and organisations. 